\title{
Inter-annual variation of shoot density and biomass, nitrogen and phosphorus content of the leaves, and epiphyte load of the seagrass Posidonia oceanica (L.) Delile off Mallorca, western Mediterranean
}

\author{
JORGE TERRADOS and FRANCISCO JAVIER MEDINA-PONS \\ Instituto Mediterráneo de Estudios Avanzados (CSIC-UIB), C/ Miquel Marqués 21, 07190 Esporles, Mallorca, Spain. \\ E-mail: terrados@imedea.uib-csic.es
}

\begin{abstract}
SUMMARY: The epiphyte load, the ash content of the epiphytes, the leaf biomass, the nitrogen and phosphorus content of the leaves, and the density of shoots of the Mediterranean seagrass Posidonia oceanica (L.) Delile were monitored yearly from 2003 to 2008 in two shallow meadows off Mallorca (western Mediterranean) with the aim of identifying the responses of $P$. oceanica meadows to mid-term environmental variability. Inter-annual variability of $P$. oceanica meadows was significant for most of the descriptors examined: shoot biomass, epiphyte load, nitrogen and phosphorus content of the leaves, and shoot density. Shoot density increased by a factor of 2 and epiphyte load by a factor of 4 from 2003 to 2008. P. oceanica descriptors were generally not correlated with each other or with the average sea surface temperature during August. Long-term data series of descriptors of $P$. oceanica status are essential to improve understanding about the response of this important Mediterranean coastal ecosystem to natural and anthropogenic disturbances and to assess the effects of rapid global environmental change.
\end{abstract}

Keywords: inter-annual variation, seagrass, epiphyte load, nitrogen, phosphorus, Posidonia oceanica, Western Mediterranean.

RESUMEN: VARIACIÓN INTERANUAL DE LA DENSIDAD DE HACES, BIOMASA FOLIAR DEL HAZ, CONCENTRACIÓN DE NITRÓGE-

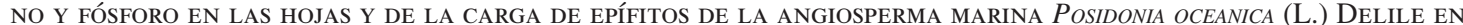
Mallorca, Mediterráneo occidental. - La carga de epífitos, el contenido en cenizas de los mismos, la biomasa foliar, el contenido en nitrógeno y fósforo de las hojas y la densidad de haces de la angiosperma marina Posidonia oceanica (L.) Delile se midieron anualmente desde 2003 a 2008 en dos praderas someras en Mallorca (Mediterráneo occidental) para identificar la respuesta de las praderas de $P$. oceanica a la variabilidad ambiental a medio plazo. Las praderas de $P$. oceanica presentan una gran variabilidad interanual pues la mayoría de los descriptores examinados (densidad de haces, biomasa foliar del haz, concentración de nitrógeno y fósforo en las hojas y carga de epífitos) cambiaron durante el periodo 2003-2008. La densidad de haces se multiplicó por dos mientras que la carga de epífitos lo hizo por cuatro. No se encontró correlación entre la mayoría de los descriptores de $P$. oceanica ni tampoco con la temperatura del agua superficial del mar en agosto. La obtención de series temporales a largo plazo sobre descriptores del estado de las praderas de $P$. oceanica es necesaria para mejorar la comprensión de las respuestas de este importante ecosistema costero del Mediterráneo a perturbaciones naturales y antropogénicas y para evaluar los efectos del cambio global.

Palabras clave: variación interanual, angiospermas marinas, epífitos, nitrógeno, fósforo, Posidonia oceanica, Mediterráneo occidental.

\section{INTRODUCTION}

Seagrass meadows are key elements of shallow coastal ecosystems because of their contribution to biological productivity and the maintenance of biodi- versity, the control of water quality and the protection of the shoreline (Orth et al., 2009). Variability in space and time are inherent to the structure and functioning of ecosystems, and seagrass meadows are highly dynamic ecosystems (Duarte et al., 2006). Temporal variability 
of seagrass biomass is a major determinant of the annual productivity of seagrass meadows, and of their trophic and structural role in shallow coastal ecosystems (Duarte, 1989). The most common temporal scale at which seagrass research is performed is the intra-annual scale, and this situation reflects the relevance attributed to seasonality to understand the structure and functioning of seagrass ecosystems. Indeed, more than two thirds of the variability of seagrass biomass is explained by seasonality (Duarte, 1989). Seagrass meadows are also variable at the inter-annual scale as a consequence of both natural processes and anthropogenic disturbances. Inter-annual variability may result from inter-annual changes in abiotic factors affecting seagrass development (i.e. temperature, light and nutrients) or from the interplay between the species-specific recruitment and growth rate characteristics of seagrasses and the frequency of natural disturbances (i.e. storms, diseases or intense grazing by herbivores: Duarte et al., 2006). Inter-annual variability of seagrass meadows may also result from the multiple direct and indirect mechanisms of local seagrass loss caused by human activities in the coastal zone and from rapid global environmental change (Orth et al., 2009).

Long-term data series are necessary to document inter-annual variability in the structure and functioning of seagrass meadows and to improve our understanding of their response to natural and anthropogenic disturbances. They can be obtained either through continuous research and monitoring efforts or, in a few cases, through the reconstruction of past seagrass performance and environmental conditions. For example, the longevous Mediterranean seagrass Posidonia oceanica (L.) Delile allows us to estimate past leaf and rhizome production using age reconstruction methods (Pergent and Pergent-Martini, 1990; Duarte et al., 1994); the pluri-annual data obtained can then be used to evaluate the effects of natural (Marbà and Duarte, 1997) or anthropogenic (Guidetti, 2001; Marbà et al., 2006) environmental changes on plant performance. The contamination history of $P$. oceanica meadows may be retrieved by analyzing the concentration of contaminants in seagrass parts of different ages (Calmet et al., 1988; Romeo et al., 1995). The marks left by inflorescences in the rhizome allow past flowerings of P. oceanica (Balestri, 2004) to be detected. In several cases, however, age reconstruction techniques cannot be used and long-term data acquisition is the only option. Shoot density, nutrient availability, epiphyte loading and herbivore pressure are examples of conditions or processes for which long-term data series should be produced to understand seagrass responses to interannual factors or to detect the effects of anthropogenic environmental changes.

Posidonia oceanica is a Mediterranean endemic seagrass species that, at depths above $40 \mathrm{~m}$, forms extensive meadows of great importance because they provide a habitat to high numbers of species and participate in biogeochemical and geological coastal processes (Procaccini et al., 2003). Light, temperature and nutrient availability are considered major abiotic factors influencing temporal variability of seagrass biomass and productivity in temperate seas (Hillman et al., 1989). P. oceanica temporal variability is mostly driven by the seasonal changes of light and temperature (Alcoverro et al., 1995; Zupo et al., 1997). Seasonality of $P$. oceanica growth implies changing nutrient requirements, and nutrient availability may therefore introduce additional seasonal variability to that driven by light and temperature, particularly at shallow depths (Alcoverro et al., 1995; Alcoverro et al., 1997a). Epiphyte load on P. oceanica shoots also shows a strong seasonality that is explained to a large extent by changes in shoot size (Alcoverro et al., 1997b; Lepoint et al., 1999). Additional seasonal variability may be introduced by nutrient loading as it promotes the development of macroalgal epiphytes in P. oceanica meadows during the summer (Leoni et al., 2006; Prado et al., 2008).

Inter-annual variability of Posidonia oceanica descriptors (sensu Pergent-Martini et al., 2005) has been much less studied than seasonality despite the fact that it is essential to detect natural or anthropogenic environmental changes and to assess the response of $P$. oceanica to them. A decrease in shoot density and an increase in mean leaf length were found by Peirano et al. (2001) near La Spezia (Italy) between 1992 and 1997. Shoot density and biomass of $P$. oceanica tended to increase in the Bay of Calvi (Corsica, France) from 1993 to 1999, while epiphyte load did not show a definite inter-annual trend (Gobert, 2002). Tagging of $P$. oceanica shoots in permanent plots and yearly censuses of the surviving and new shoots has shown inter-annual variability of shoot mortality between 2002 and 2006 off Cabrera Island (Mallorca, Spain) and that the highest mortality rates occurred in years with the warmest summers (Marbà and Duarte, 2010).

Given the strong effects that light, temperature and nutrient availability have on the seasonality of vegetative development and epiphyte loading in P. oceanica, we surmise that inter-annual differences in these abiotic factors may also drive inter-annual differences in the vegetative development achieved by this seagrass species and of its epiphyte load. The biomass of $P$. oceanica shoots reaches maximum values during the summer (Alcoverro et al., 1995), while the high nutrient requirements imposed by high rates of leaf growth maintained since the end of spring cause the concentration of nutrients in the leaves to reach minimum values at the end of summer (Alcoverro et al., 1997a). The biomass of $P$. oceanica epiphytes also reaches high values at the end of summer (Romero, 1988; Alcoverro et al., 1997b) and increased nutrient availability during this season promotes further epiphyte development (Leoni et al., 2006; Prado et al., 2008). Low light availability (Ruiz and Romero, 2001) and herbivory (Alcoverro et al., 1997b; Tomas et al., 2005) restrain the development of epiphytes on P. oceanica leaves. Hence, dif- 
ferences in temperature, light and nutrient availability and herbivore pressure between years may affect the biomass, nutrient content and epiphyte load of $P$. oceanica shoots at the end of summer. In this study we assess inter-annual variation of selected $P$. oceanica descriptors with the aim of identifying the responses of $P$. oceanica meadows to mid-term environmental variability. To this end we estimated the shoot density and biomass, nitrogen and phosphorus content of the leaves and epiphyte load of $P$. oceanica shoots at the end of summer at two locations off Mallorca (western Mediterranean) from 2003 to 2008.

\section{MATERIALS AND METHODS}

The study was performed at two locations on the south coast of Mallorca island (W Mediterranean): Magaluf (39'30'15.5'N; 2'32'35.7'E) and Ses Salines $\left(39^{\circ} 15^{\prime} 44.6^{\prime \prime} \mathrm{N}\right.$; 3 $\left.3^{\circ} 7^{\prime \prime} \mathrm{E}\right)$. Depth was $8 \mathrm{~m}$ at the two locations. Five Posidonia oceanica shoots were haphazardly collected along each of two 10-m-long transects that were $30 \mathrm{~m}$ apart in order to estimate the leaf biomass, nitrogen and phosphorus concentration, and the epiphyte load of the shoots $(n=10)$ at each location and year. Sampling was performed in September of the years 2003 to 2008, the time of year when the $P$. oceanica shoots achieve maximum biomass (Alcoverro et al., 1995) and the epiphytic community reaches a maximum seasonal development as a result of the proliferation of opportunistic species of macroalgae (Ballesteros, 1987; Romero, 1988). Nutrient concentration in $P$. oceanica leaves is expected to be low at this time of the year (Alcoverro et al., 1997a; Fourqurean et al., 2007) and for this reason inter-annual differences of nutrient concentration in the leaves at the end of summer are more likely to reflect differences of nutrient availability between years, as nutrient-addition experiments show (Leoni et al., 2007; Prado et al., 2008).

The epiphytes in all the leaves of each Posidonia oceanica shoot were scraped using a razor blade and collected in pre-weighed Whatman GF/C glass fibre filters which were dried $\left(60^{\circ} \mathrm{C}, 48 \mathrm{~h}\right)$ to estimate their dry weight. The dried epiphytes of 6 out of the 10 shoots collected at each location and year were burned $\left(450^{\circ} \mathrm{C}, 6 \mathrm{~h}\right)$ to determine their ash content. The ash content of the epiphytes was determined to detect any major differences in the proportion of encrusting coralline algae and zooepiphytes to filamentous algae in the epiphytic community between years and locations. The leaves were also dried $\left(60^{\circ} \mathrm{C}, 48 \mathrm{~h}\right)$ to estimate the biomass of each shoot. Epiphyte load was calculated as the biomass of leaf epiphytes in the shoot divided by the leaf biomass of the shoot ( $g$ epiphyte DW $\mathrm{g}^{-1}$ leaf DW). Dried leaves were ground to powder with a stainless steel ball mill (MM200 RETSCH, Haan, Germany) and a sub-sample of dried leaves of 6 out of the 10 shoots collected at each location and year was used to determine the concentration of nitrogen and phosphorus in the leaves. Nitrogen and phosphorus leaf content were considered as relative indicators of nutrient availability to seagrass (Duarte, 1990; McClelland and Valiela, 1998; Fourqurean et al., 2007; Pérez et al., 2008). Nitrogen content was determined using a Heraeus CHN-o-rapid elemental analyzer. Phosphorus content was determined using the dry-oxidation, acid hydrolysis method of Fourqurean et al. (1992).

The density of Posidonia oceanica shoots was estimated from the counts of the number of shoots present inside $400 \mathrm{~cm}^{2}$ quadrats placed every metre along the transects $(n=20)$. No sea urchins were observed during sampling at any location. The number of bite marks of the sparid fish Salpa sarpa L. on the leaves (Buia et al., 2003) of all the shoots collected was counted and the overall mean ( \pm standard error) was not different between locations (Magaluf: $2.3 \pm 1.3$ bites per shoot; Ses Salines: $2.2 \pm 2.3$ bites per shoot). We did not evaluate differences in the number of bite marks per shoot between years because we considered that the number of shoots inspected each year was too low to provide reliable estimates of $S$. sarpa herbivore pressure.

Monthly average temperature of surface sea water (SST) and chlorophyll concentration at sea surface on the south coast of Mallorca were extracted from satellite data provided by Gruppo di Oceanografía da Satellite-GOS (Istituto di Scienze dell'Atmosfera e del Clima, Consiglio Nazionale delle Ricerche, Rome, Italy). Data from NOAA/AVHRR and Seastar/SeaWiFS images covering the Mediterranean Sea are acquired and processed daily by GOS to generate SST and ocean colour datasets with a spatial resolution of $1 / 16^{\circ}$ (Marullo et al., 2007; Santoleri et al., 2008; for further details see http://gos.ifa.rm.cnr.it). Monthly average sea water temperature at two locations next to south coast of Mallorca (Mitjana Island, $11 \mathrm{~m}$ depth and Cala D'Or Bay, 8 m depth) was also calculated from datasets generated by StowAway Tidbit temperature loggers (Onset Computer Corporation, Bourne, MA, USA) that were deployed at these locations for a few months while this study was being done (author's unpublished data). We chose the average SST in August as the variable to correlate with $P$. oceanica descriptors because August is the warmest month of the year in the western Mediterranean and inter-annual differences of sea water temperature might drive inter-annual variability of shoot biomass and epiphyte load. Additionally, interannual variability of chlorophyll concentration at sea surface might result in inter-annual differences of light availability for seagrass and epiphyte growth.

Two-way analysis of variance was used to determine whether there were differences in shoot biomass, epiphyte load, ash content of the epiphytes, nitrogen and phosphorus content of the leaves and shoot density of Posidonia oceanica between years and locations. For significant sources of variation the Tukey HSD test was used to evaluate the significance of differences between particular years and locations. The Spearman rank correlation analysis was used to determine whether there was any association between the values reached 
by shoot biomass, epiphyte load, ash content of the epiphytes, and the nitrogen and phosphorus content of the leaves at each location and between locations. Spearman rank correlation analysis was also used to evaluate the association between $P$. oceanica descriptors and the average SST and chlorophyll concentration at sea surface in August. STATISTICA software (Statsoft, Inc., 2005) was used to perform these analyses.

\section{RESULTS}

Sea surface temperature in the south of Mallorca showed a strong seasonality with minimum values in February-March and maximum values in August (Fig. 1). August 2003 was the warmest in the series, while the months of February and March of 2005 and 2006 were the coldest. The composite series of seawater temperature at two locations near the south coast of Mallorca (Mitjana Island and Cala D'Or Bay) and depth above the seasonal thermocline showed minimal inter-annual variability during August from 2004 to 2008 and the coldest years were also 2005 and 2006. The concentration of chlorophyll at the sea surface showed a definite seasonality that was opposite to that of SST: the maximum annual values were reached in February-March each year and the minimum values were reached in July-August (Fig. 1). Summer chlorophyll concentration was always below $0.05 \mathrm{mg} \mathrm{m}^{-3}$.

The biomass of Posidonia oceanica shoots was lower at Magaluf than at Ses Salines (Fig. 1, Table 1). Shoot biomass at Magaluf decreased from $0.8 \pm 0.1$ (mean \pm 1 standard error) $\mathrm{gDW}$ shoot $^{-1}$ in 2003 to about $0.4 \mathrm{~g} \mathrm{DW} \mathrm{shoot}^{-1}$ in 2005 and 2006 and increased to more than $0.6 \mathrm{~g} \mathrm{DW}$ shoot $^{-1}$ in 2007 and 2008. Shoot biomass at Ses Salines dropped by $30 \%$ in 2006 and 2007 relative to the rest of the years (Fig. 1). The minimum values of shoot biomass were found in 2005-2006 at Magaluf and in 2006-2007 at Ses Salines.

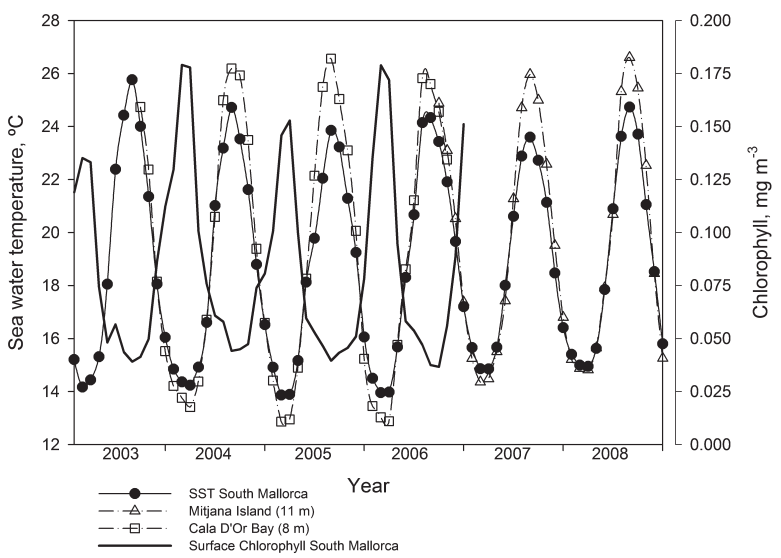

FIG. 1. - Monthly average surface sea water temperature (SST, 2003 to 2008) and chlorophyll concentration at the sea surface (2003 to 2006) in the south of Mallorca (western Mediterranean) calculated from satellite images. The monthly average of seawater temperature recorded at two shallow locations on the south coast of Mallorca (squares: Cala D'Or Bay, 9/2003 to 10/2006; triangles: Mitjana Island, $9 / 2006$ to $12 / 2008$ ) is also included.
TABLE 1. - Results of analysis of variance (DF, degrees of freedom; MS, mean square; F, F-ratio) to determine whether there were differences in shoot biomass, epiphyte load, ash content of epiphytes, nitrogen and phosphorus content of the leaves and shoot density of Posidonia oceanica between years (2003 to 2008) and locations (Magaluf, Ses Salines) off Mallorca, western Mediterranean. Significant sources of variation are indicated by asterisks: $*, P<0.05$; **, $P<0.01$; ***. $P<0.001$. $\S$ Data were log-transformed. \# Data transformation did not homogenize variances.

\begin{tabular}{|c|c|c|c|c|}
\hline & Source of variation & DF & MS & $\mathrm{F}$ \\
\hline \multirow[t]{4}{*}{ Shoot biomass } & Year, Y & 5 & 0.2958 & $3.63 * *$ \\
\hline & Location, L & 1 & 2.0457 & $25.15 * * *$ \\
\hline & Y x L & 5 & 0.2058 & $2.53 *$ \\
\hline & Error & 98 & 0.08135 & \\
\hline \multirow[t]{4}{*}{ Epiphyte load \# } & Year, Y & 5 & 0.2654 & $8.33 * * *$ \\
\hline & Location, L & 1 & 1.5710 & $49.29 * * *$ \\
\hline & $\mathrm{Y} \times \mathrm{L}$ & 5 & 0.0613 & 1.92 \\
\hline & Error & 98 & 0.0319 & \\
\hline \multirow[t]{4}{*}{ Epiphyte ash } & Year, Y & 5 & 17.0 & 1.72 \\
\hline & Location, L & 1 & 262.7 & $26.57 * * *$ \\
\hline & Y x L & 5 & 11.4 & 1.15 \\
\hline & Error & 54 & 9.9 & \\
\hline \multirow[t]{4}{*}{ Leaf Nitrogen \# } & Year, Y & 5 & 0.2224 & $3.98 * *$ \\
\hline & Location, L & 1 & 0.2171 & 3.89 \\
\hline & Y x L & 5 & 0.0164 & 0.29 \\
\hline & Error & 54 & 0.0558 & \\
\hline \multirow[t]{4}{*}{ Leaf Phosphorus } & Year, Y & 5 & 0.0016 & $6.03 * * *$ \\
\hline & Location, L & 1 & 0.0282 & $103.29 * * *$ \\
\hline & $Y \times L$ & 5 & 0.0008 & $3.03 *$ \\
\hline & Error & 74 & 0.0003 & \\
\hline \multirow[t]{4}{*}{ Shoot density $\S$} & Year, Y & 3 & 0.5196 & $26.77 * * *$ \\
\hline & Location, L & 1 & 1.3006 & $67.01 * * *$ \\
\hline & Y x L & 3 & 0.0832 & $4.29 * *$ \\
\hline & Error & 118 & 0.0194 & \\
\hline
\end{tabular}

The epiphyte load of Posidonia oceanica shoots was higher at Magaluf than at Ses Salines and increased at both locations during the study, particularly from 2003 to 2005 , when it changed from $0.13 \pm 0.03 \mathrm{~g}$ epiphyte DW g-1 leaf DW to $0.57 \pm 0.06 \mathrm{~g}^{-1}$ epiphyte DW $\mathrm{g}^{-1}$ leaf DW at Magaluf (post-hoc Tukey HSD $<0.05$ ), and from $0.07 \pm 0.01 \mathrm{~g}$ epiphyte DW $\mathrm{g}^{-1}$ leaf DW to $0.26 \pm 0.04$ g epiphyte DW g-1 leaf DW at Ses Salines (post-hoc Tukey HSD<0.05). No consistent temporal trend was observed afterwards (Fig. 1).

The ash content of Posidonia oceanica epiphytes was lower at Magaluf $(81.6 \pm 0.6 \%$ epiphyte DW) than at Ses Salines $(85.5 \pm 0.5 \%$ epiphyte DW) but no significant differences between years were found at any of the two locations (Fig. 1, Table 1).

The nitrogen content of Posidonia oceanica leaves was similar at Magaluf and Ses Salines, decreasing from slightly above $1 \%$ leaf DW in 2003 to $0.7-0.8 \%$ leaf DW in 2004-2005 and increasing afterwards (posthoc Tukey HSD<0.05) to reach values at or above $1 \%$ leaf DW in 2007 and 2008 (Fig. 1, Table 1). The C:N molar ratio varied between 38 and 54 at Magaluf, while it varied between 34 and 47 at Ses Salines. The phosphorus content of $P$. oceanica leaves was higher at Magaluf $(0.08 \pm 0.003 \%$ leaf DW) than at Ses Salines $(0.05 \pm 0.003 \%$ leaf DW). Leaf phosphorus decreased from $0.12 \pm 0.01 \%$ leaf DW in 2003 to $0.06 \pm 0.01 \%$ leaf DW at Magaluf (Fig. 1, Table 1, post-hoc Tukey HSD<0.05), while at Ses Salines it did not change during the study (post-hoc Tukey HSD tests, $P>0.13$ ). The 

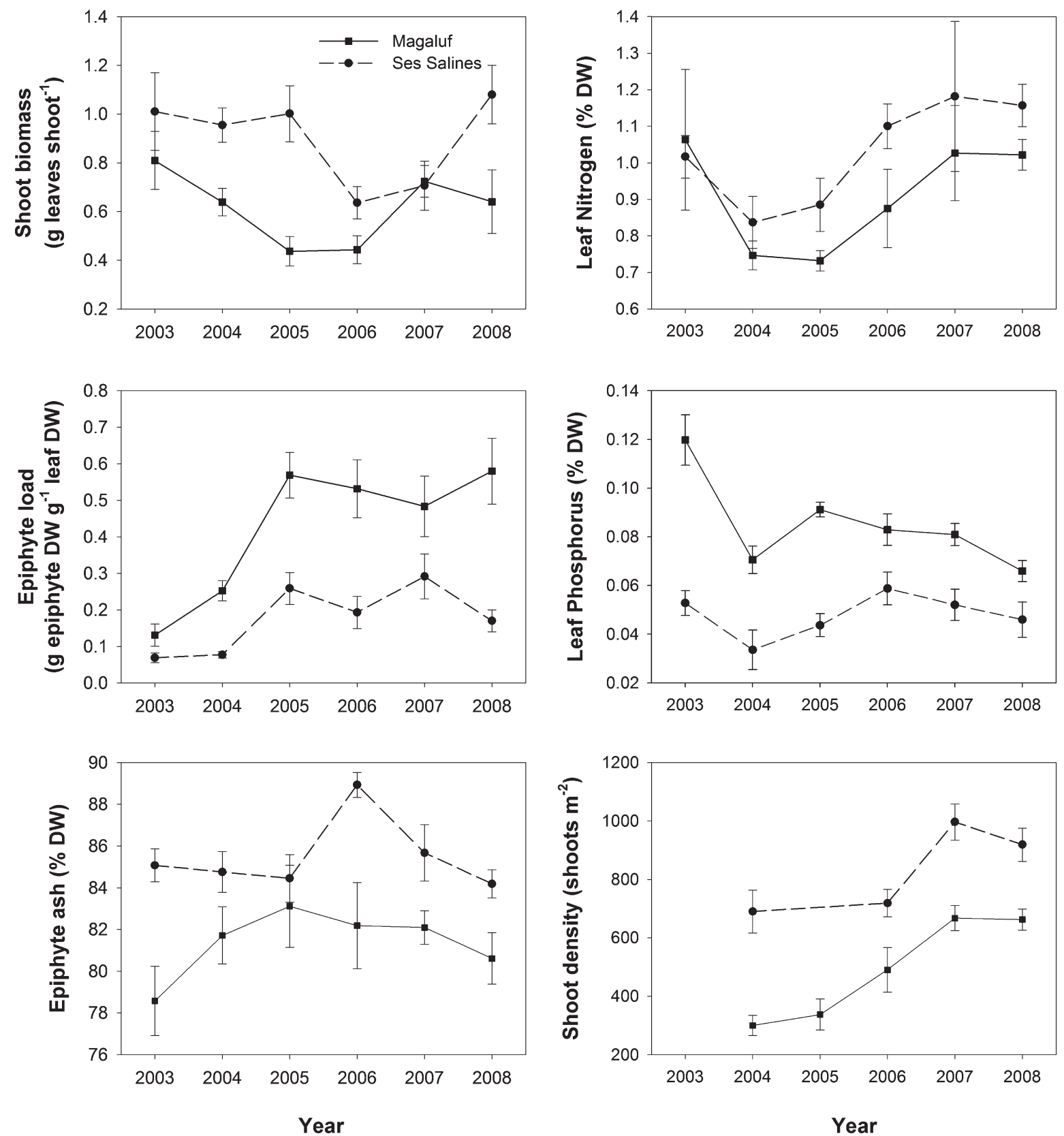

FIG. 2. - Shoot biomass, epiphyte load, ash content of the epiphytes, nitrogen and phosphorus content of the leaves and shoot density of Posidonia oceanica at Magaluf and Ses Salines, Mallorca (western Mediterranean) from 2003 to 2008. Error bars represent \pm 1 standard error. The year 2005 was not included in the analysis of shoot density because no data were collected at Ses Salines that year.

molar N:P ratio varied between 18 and 34 at Magaluf, and between 41 and 56 at Ses Salines.

Shoot density of Posidonia oceanica was always higher at Ses Salines than at Magaluf (Table 1, Fig. 1) and increased at both locations: from 300 shoots $\mathrm{m}^{-2}$ in 2004 to more than 600 shoots $\mathrm{m}^{-2}$ in 2007 and 2008 at Magaluf, and from about 700 shoots $\mathrm{m}^{-2}$ in 2004-2006 to more than 900 shoots $\mathrm{m}^{-2}$ in 2007 and 2008 at Ses Salines (Table 1, Fig. 1). Shoot density was not correlated with August SST at either of the two locations between 2004 and 2008.
Except for shoot biomass and the nitrogen content of Posidonia oceanica leaves at Magaluf, the epiphyte load, foliar nutrients and shoot biomass were not correlated (Table 2, above and below main diagonal). The ash content of $P$. oceanica epiphytes was, however, negatively correlated with shoot biomass at both locations. Shoot biomass, epiphyte load, epiphyte ash and nitrogen and phosphorus content of $P$. oceanica leaves were not correlated between locations either (Table 2, main diagonal). The epiphyte load was negatively correlated with August SST at Ses Salines but not at 
TABLE 2. - Results of Spearman rank correlation analysis evaluating the association between shoot biomass, epiphyte load, ash content of the epiphytes, and nitrogen and phosphorus content of the leaves of Posidonia oceanica and August SST at Magaluf (above main diagonal) and Ses Salines (below main diagonal) during the 2003-2008 period. Correlations of P. oceanica descriptors between Magaluf and Ses Salines are presented in main diagonal. *, $P<0.05$.

\begin{tabular}{|c|c|c|c|c|c|c|}
\hline & Shoot biomass & Epiphyte load & Epiphyte ash & Leaf phosphorus & Leaf nitrogen & August SST \\
\hline Shoot biomass & 0.31 & -0.54 & $-0.83 *$ & 0.03 & $0.94 *$ & 0.43 \\
\hline Epiphyte load & -0.48 & 0.48 & 0.43 & -0.43 & -0.43 & -0.26 \\
\hline Epiphyte ash & $-0.83^{*}$ & 0.20 & 0.20 & 0.14 & -0.71 & $-0.83 *$ \\
\hline Leaf phosphorus & -0.31 & 0.03 & 0.71 & $\underline{0.43}$ & 0.14 & 0.03 \\
\hline Leaf nitrogen & -0.09 & 0.48 & 0.26 & 0.54 & 0.60 & 0.37 \\
\hline August SST & 0.66 & $-0.94 *$ & -0.31 & 0.08 & $-\overline{0.26}$ & -- \\
\hline
\end{tabular}

Magaluf. The ash content of the epiphytes was negatively correlated with August SST at Magaluf but not at Ses Salines. The chlorophyll concentrations at sea surface in August was not correlated with any P. oceanica descriptor.

\section{DISCUSSION}

Inter-annual variability of Posidonia oceanica meadows at Magaluf and Ses Salines during the 20032008 period was significant for most part of the descriptors examined: shoot biomass, epiphyte load, nitrogen and phosphorus content of the leaves, and shoot density. Large differences between years (from 1993 to 1999) were also found in a $P$. oceanica meadow in the Bay of Calvi (Gobert, 2002), the only other study in which the inter-annual variability of an ample suite of $P$. oceanica descriptors has been quantified. Hence, temporal variability of $P$. oceanica meadows has both a seasonal (Romero, 1988; Alcoverro et al., 1995; Alcoverro et al., 1997a; Zupo et al., 1997) and an interannual component (Gobert, 2002; this study). Spatial variability of $P$. oceanica descriptors (Balestri et al., 2003; Gobert et al., 2003) and of its leaf epiphytic community (Pardi et al., 2006; Balata et al., 2007; Piazzi et $a l ., 2007)$ is also significant at different scales. Thus in spite of their apparent homogeneity P. oceanica meadows are highly variable in both space and in time.

Particularly relevant was the sustained increase in shoot density that we found at Magaluf and Ses Salines. Although no true long-term data series of $P$. oceanica descriptors is available for the western Mediterranean, information about inter-annual variability of shoot density is increasing (Table 3). Gains and losses of 100-200 shoots $\mathrm{m}^{-2}$ are common in pluri-annual series of shoot density estimates. A consistent trend of reduction of $P$. oceanica shoot density between 1992 and 1997 resulted in the loss of about 100 shoots $\mathrm{m}^{-2}$ in meadows located at depths of 5 and $10 \mathrm{~m}$ in a marine protected area near La Spezia (Peirano et al., 2001). The shoot density of a $P$. oceanica meadow at the depth of $10 \mathrm{~m}$ in the Bay of Calvi decreased from about 500 shoots $\mathrm{m}^{-2}$ in 1991 to about 300 shoots $\mathrm{m}^{-2}$ in 1994 and 1997, followed by an increase to more than 500 shoots $\mathrm{m}^{-2}$ in 1998 and a reduction to about 400 shoots $\mathrm{m}^{-2}$ in 1999 (Gobert, 2002). Changes in shoot density between years of the same magnitude have also been found in Catalonia (Sánchez-Rosas and Prats-Olivella, 2009), Murcia (Ruiz-Fernández et al., 2009) and the Balearic Islands (Álvarez et al., 2009). Additionally, the shoot density of permanent $P$. oceanica plots situated at depths of $10 \mathrm{~m}$ or less off Cabrera Island (Marbà and Duarte, 2010) was reduced by 100-200 shoots $\mathrm{m}^{-2}$ from 2002 to 2003 followed by increases of the same magnitude from 2003 to 2004 and reductions of 50100 shoot $\mathrm{m}^{-2}$ from 2004 to 2006 . The magnitude of the increase in shoot density that we found at Magaluf and Ses Salines is therefore similar to that of previous records of shoot density gains or losses in pluri-annual data series.

The available evidence for the Balearic Islands (Álvarez et al., 2009; this study) suggests that shoot density of Posidonia oceanica meadows was either stable or increasing during the 2003-2008 period, which contrasts with results from other studies that found a net reduction in shoot density on permanent plots where $P$. oceanica shoots are tagged and counted yearly (Marbà and Duarte, 2010). Annual monitoring of shoot density may not be sensitive enough to detect shoot density changes unless a large number of replicated counts are done (Marbà et al., 2005), but by averaging shoot density values from a large meadow surface the results might better reflect net shoot balances at the meadow scale. The intensive labour required by a yearly shoot

TABLE 3. - Inter-annual trends of shoot density of Posidonia oceanica meadows in the western Mediterranean. The number of meadows where shoot density was either increasing, stable or decreasing during the years indicated is presented. Only those meadows with a minimum of four years of data within the indicated period are included.

\begin{tabular}{|c|c|c|c|c|c|}
\hline \multirow[t]{2}{*}{ Region/Location } & \multirow[t]{2}{*}{ Years } & \multicolumn{3}{|c|}{ Shoot density } & \multirow[t]{2}{*}{ Source } \\
\hline & & Increasing & Stable & Decreasing & \\
\hline Monterosso al Mare, La Spezia, Italy & 1992-1997 & 0 & 0 & 3 & Peirano et al., 2001 \\
\hline Bay of Calvi, Corsica, France & 1991-1999 & 0 & 1 & 0 & Gobert, 2002 \\
\hline Catalonia, Spain & $1998-2006$ & 4 & 16 & 2 & Sánchez-Rosas and Olivella-Prats, 2009 \\
\hline Murcia, Spain & 2004-2007 & 2 & 6 & 6 & Ruiz-Fernández et al., 2009 \\
\hline Balearic Islands, Spain & 2002-2007 & 7 & 2 & 0 & Álvarez et al., 2009 \\
\hline Mallorca, Spain & 2004-2008 & 2 & 0 & 0 & This study \\
\hline
\end{tabular}


census on permanent plots means that the number of plots is small (Marbà et al., 2005) and because plagiotropic, horizontally-growing rhizomes produce many more new shoots than orthotropic, vertically-growing rhizomes (González-Correa et al., 2007), census data might reflect actual net shoot balances at the meadow scale only if the permanent plots used to obtain them sample the density of plagiotropic rhizomes in the meadow accurately. Although further research should be done to resolve this contradiction, the extremely warm summer of 2003 seems to have increased the mortality rate of $P$. oceanica shoots (Marbà and Duarte, 2010). The increase in shoot density that we found between 2004 and 2008 might reflect the recovery of shoot density after a minimum value of shoot density reached in 2004 as a consequence of the 2003 summer related event of high shoot mortality. The summer of 2006 was also very warm and promoted an increase in shoot mortality (Marbà and Duarte, 2010) but we did not detect a reduction in shoot density in 2007 at Magaluf or Ses Salines.

The disparity of the inter-annual trends detected by different studies (Table 3) suggests that local conditions and processes may have a large influence on the inter-annual variability of shoot density. Indeed, Posidonia oceanica meadows with no evidence of anthropogenic disturbances show predominantly stable shoot density, while those where anthropogenic influences are clear show predominantly a reduction in shoot density (Ruiz-Fernández et al., 2009). The comparison of the growth of plagiotropic rhizomes of $P$. oceanica in pristine areas also led González-Correa et al. (2007) to suggest that most declines in $P$. oceanica meadows might be driven by local conditions and processesmainly anthropogenic.

The biomass of Posidonia oceanica shoots at Ses Salines was similar to that of the shoots in a $P$. oceanica meadow at a depth of $10 \mathrm{~m}$ in the Bay of Calvi (mean shoot biomass, September 1992-1999: 1 g DW shoot $^{-1}$; Gobert, 2002), but shoot biomass at Magaluf was at least $20 \%$ lower. The biomass of $P$. oceanica shoots at Magaluf and Ses Salines is similar to values found in the other meadows throughout the Balearic Islands (mean shoot biomass, $0.7 \mathrm{~g} \mathrm{DW}$ shoot $^{-1}$ [Fourqurean et al., 2007]; mean shoot biomass in September of 2004-2006, $0.6 \mathrm{~g} \mathrm{DW} \mathrm{shoot}^{-1}$ [Terrados and MedinaPons, 2008]). The lack of correlation between August SST and shoot biomass suggests that inter-annual changes in shoot biomass are not driven by inter-annual changes in summer temperature. The shallow depth of the meadows studied and the constant low values of chlorophyll at sea surface in summer suggest that inter-annual differences in light availability may not have a major influence on the biomass achieved by $P$. oceanica shoots in summer. Inter-annual changes in temperature and number of hours of sunlight were not able to explain changes in shoot biomass of a $P$. oceanica meadow in the Bay of Calvi (Gobert, 2002). Sea water temperature and light availability may be the main abiotic factors explaining the seasonality of the vegetative development of $P$. oceanica (Alcoverro et al., 1995; Zupo et al., 1997), but they seem to have a limited capacity to explain its inter-annual variability.

The nitrogen and phosphorus content of Posidonia oceanica leaves at Magaluf and Ses Salines was lower than values found previously in the Balearic Islands $(\mathrm{N}$, $1.6 \%$ leaf DW; P, $0.12 \%$ leaf DW [Fourqurean et al., 2007]) and on the NE coast of Spain (N, 1.7-2.4\% leaf DW; P, 0.12-0.16\% leaf DW [Alcoverro et al., 1995]. However, other $P$. oceanica meadows in Mallorca (i.e. Cabrera Island) show similar values of leaf nitrogen (0.8-1.1\% leaf DW [Terrados and Medina-Pons, 2008]), and similar (compared to Magaluf) or higher (compared to Ses Salines) values of leaf phosphorus (0.08-0.13\% leaf DW [unpublished data]). The molar $\mathrm{C}: \mathrm{N}$ ratios of $P$. oceanica leaves at Magaluf and Ses Salines are higher than the median of the values found at other locations throughout the Balearic Islands (C:N=28 [Fourqurean et al., 2007]) and point to nitrogen deficiency of $P$. oceanica at the end of summer. The molar N:P ratios of $P$. oceanica leaves at Magaluf are similar to those found at other locations in the Balearic Islands (N:P=29 [Fourqurean et al., 2007]), but the N:P ratio at Ses Salines was higher. Hence, the $P$. oceanica meadow at Ses Salines seems to experience a strong nitrogen and phosphorus deficiency at the end of summer.

The nutrient content of seagrass leaves is the result of the balance between nutrient availability and nutrient requirements. Low light availability may reduce seagrass growth and consequently seagrass nutrient requirements, resulting in an increase in seagrass nutrient content (Abal et al., 1994). In contrast, high growth rates in spring and summer, when there is an ample supply of light, may lead to a reduction in the internal concentration of nutrients (Alcoverro et al., 1997a). The annual minimum concentrations of nutrients in the leaves of Posidonia oceanica in summer are interpreted as the result of this balance between nutrient availability and requirements (Alcoverro et al., 1997a; Fourqurean et al., 2007), indicating that summer is a season when the relative nutrient availability to seagrass growth is lowest. Indeed, nutrient-addition experiments show that it is in summer when the magnitude of $P$. oceanica responses to increased nutrient availability is highest (Leoni et al., 2006, Leoni et al., 2007; Prado et al., 2008). We surmised, therefore, that inter-annual differences of nutrient concentration in the leaves of $P$. oceanica at the end of summer might indicate inter-annual changes in nutrient availability for seagrass growth during summer.

Increased nutrient availability in Posidonia oceanica meadows commonly results in increased leaf growth (Alcoverro et al., 1997a; Gobert, 2002) and leaf length (Leoni et al., 2006), especially in summer and at shallow depths. Hence, we expected to find a positive correlation between shoot biomass and the nutrient content of the leaves at the end of summer. However, 
only the nitrogen content of the leaves at Magaluf was positively correlated with shoot biomass. Molar C:N and N:P ratios were not correlated with shoot biomass at either of the two locations studied. Inter-annual variability of the biomass of $P$. oceanica shoots at Magaluf and Ses Salines seems uncoupled from inter-annual changes in nutrient availability. The reduction of the concentration of nitrogen in the leaves of $P$. oceanica at both locations in 2004 might be related to the flowering event of year 2003. Increased flowering increases the nutrient requirements of $P$. oceanica shoots (Gobert, 2002) and an associated reduction in nitrogen concentration in the leaves of the flowering shoots has also been observed previously (Gobert, 2002).

The epiphyte load on Posidonia oceanica shoots at Ses Salines was lower than the values found off Cabrera Island at the same time of the year (mean epiphyte load in 2004-06 was 0.3 $\mathrm{g} \mathrm{DW} \mathrm{g}^{-1}$ leaf DW [Terrados and Medina-Pons, 2008]) but similar to those found in the Bay of Calvi (mean epiphyte load in 1992-99 was $0.2 \mathrm{~g} \mathrm{DW} \mathrm{g}^{-1}$ leaf DW [Gobert, 2002]). The epiphyte load in Magaluf shoots from 2005 to 2008 was higher than that off Cabrera Island and in the Bay of Calvi.

Grazing pressure and nutrient availability are considered to be major sources of variability of epiphyte biomass in seagrass meadows (Borowitzka et al., 2006). Sea urchins and herbivore fishes reduce the epiphyte load on Posidonia oceanica leaves (Alcoverro et al., 1997b; Ruiz et al., 2001; Tomas et al., 2005). Our data do not allow us to determine whether inter-annual differences in herbivore pressure drive the observed inter-annual variability of epiphyte load at Magaluf and Ses Salines. Nutrient-addition experiments have shown that the $P$. oceanica epiphytic community responds in summer to the rise in the availability of nutrients with an increase in algal biomass (Leoni et al., 2006; Prado et al., 2008). The nutrient concentration of seagrass epiphytes is considered a good indicator of nutrient availability in the water column (Pérez et al., 2008 ) and, because the concentrations of nutrients in $P$. oceanica leaves and epiphytes are positively correlated (Alcoverro et al., 1997b), we assumed that inter-annual changes in nutrient concentration in $P$. oceanica leaves may reflect inter-annual variability of nutrient availability not only for $P$. oceanica but also for its epiphytic algae. Thus, the lack of correlation between the epiphyte load of $P$. oceanica shoots and the nutrient content of the leaves at Magaluf and Ses Salines suggests that inter-annual variability of epiphyte load in 2003-2008 was not driven by inter-annual differences in nutrient availability. August SST was negatively correlated with epiphyte load at Ses Salines but not at Magaluf, which suggests that inter-annual variability of seawater temperature might drive changes in epiphyte load but that other conditions or processes must also be relevant.

The epiphyte load on Posidonia oceanica shoots increased four times from 2003 to 2005 at both Magaluf and Ses Salines and remained invariant until 2008. This increase was probably not associated with major changes in the ratio of encrusting coralline to filamentous algae at any of the two locations because the ash content of the epiphytes did not change between years. The lack of correlation between epiphyte ash and the nitrogen and phosphorus content of $P$. oceanica leaves at the two locations further suggests that inter-annual changes in nutrient availability might not have a major influence on the ratio of encrusting coralline to filamentous algae, as indicated by the ash content of the epiphytes.

The negative correlation between shoot biomass and the ash content of the epiphytes that we found at both locations suggests that encrusting coralline algae might be more abundant in small than in large $P$. oceanica shoots. Encrusting coralline algae are an important component of the macroalgal epiphytic community over the entire depth range of $P$. oceanica meadows (Mazzella et al., 1989; Tsirika et al., 2007; Nesti et al., 2009), which indicates that they tolerate a wide range of light levels (Dalla Via et al., 1998). Shading within a $P$. oceanica canopy may be quite important (Dalla Via et al., 1998) and small shoots inside the leaf canopy are probably under lower light levels than their neighbouring larger shoots. The abundance of encrusting coralline algae might be higher in small than in large $P$. oceanica shoots if encrusting coralline algae tolerate lower light levels than other algal groups (Airoldi, 2000; Figueiredo et al., 2000).

A consistent difference between Magaluf and Ses Salines in most of the Posidonia oceanica descriptors was detected. The P. oceanica meadow at Magaluf had lower shoot density, smaller shoots, higher epiphyte load and lower ash content in epiphytes than the one at Ses Salines. The nutrient concentration in the leaves and molar $\mathrm{C}: \mathrm{N}$ and $\mathrm{N}: \mathrm{P}$ ratios indicate that phosphorus availability is lower at Ses Salines than at Magaluf. The higher ash content of the epiphytes at Ses Salines than at Magaluf suggests that encrusting coralline algae and/or zooepiphytes are a more important component of the epiphytic community there than at Magaluf. The apparent scarcity of sea urchins at Magaluf and Ses Salines and the similar abundance of Salpa sarpa bite marks at the two locations suggest that the differences in epiphyte load between the two locations are not driven by differences in herbivore pressure. Differences in P. oceanica descriptors between Magaluf and Ses Salines might be related to a different level of anthropogenic influence between the two sites, although no direct sources of anthropogenic disturbance can be identified in the two meadows studied. Magaluf is located within the Bay of Palma, which holds Mallorca's main harbour, the city of Palma, and a resident population of 489122 inhabitants, while the resident population near Ses Salines is 17934 inhabitants only (source: Instituto Nacional de Estadística, Spain, www.ine.es, date of access 16/02/2010). Using resident population as an indicator of anthropogenic influence, the status of $P$. oceanica is more likely to be influenced by human activities at Magaluf than at Ses Salines. 
In summary, annual monitoring of two shallow Posidonia oceanica meadows off Mallorca (western Mediterranean) detected significant inter-annual changes in shoot density, shoot biomass, epiphyte load on the shoots, and nitrogen and phosphorus content of the leaves from 2003 to 2008. Shoot density increased by a factor of two and epiphyte load by a factor of four. $P$. oceanica descriptors were generally not correlated to each other or with the average sea surface temperature in August. This study did not allow us to identify the mechanisms generating inter-annual variability of $P$. oceanica meadows, and this is a research topic that deserves further attention. Explaining inter-annual variability of $P$. oceanica descriptors in 2003-2008 has proven to be a difficult task. Long-term data series of descriptors of $P$. oceanica status are necessary to improve our understanding of the response of this important Mediterranean coastal ecosystem to natural and anthropogenic disturbances and to assess the effects of fast global environmental change. This study provides a useful term of reference for assessing the future status of $P$. oceanica meadows.

\section{ACKNOWLEDGEMENTS}

F. J. Medina-Pons was supported by a $\mathrm{PhD}$ grant (FPI05) of the Govern de les Illes Balears. Research funds were provided by the Ministerio de Medio Ambiente, project 055/2002 and by the Govern de les Illes Balears, UGIZC project. We thank J. Fourqurean (Florida International University) for his advice on the phosphorus analysis, B. Buongiorno Nardelli (GOSISAC-CNR, Rome, Italy) for granting access to the satellite data, and E. Vidal and A. Pascual (IMEDEA, CSIC-UIB) for their help in extracting the satellite data corresponding to the south of Mallorca. We thank the reviewers for their useful comments, which improved the manuscript greatly.

\section{REFERENCES}

Abal, E.G., N.R. Loneragan, P. Bowen, C.J. Perry, J.W. Udy and W.C. Dennison. - 1994. Physiological and morphological responses of the seagrass Zostera capricorni Aschers. to light intensity. J. Exp. Mar. Biol. Ecol., 178: 113-129.

Airoldi, L. - 2000. Effects of disturbance, life histories, and overgrowth on coexistence of algal crusts and turfs. Ecology, 81: 798-814.

Alcoverro, T., C.M. Duarte and J. Romero. - 1995. Annual growth dynamics of Posidonia oceanica: contribution of large-scale versus local factors to seasonality. Mar. Ecol. Prog. Ser., 120: 203-210.

Alcoverro, T., J. Romero, C.M. Duarte and N.I. López. - 1997a. Spatial and temporal variations in nutrient limitation of seagrass Posidonia oceanica growth in the NW Mediterranean. Mar. Ecol. Prog. Ser., 146: 155-161.

Alcoverro, T., C.M. Duarte and J. Romero. - 1997b. The influence of herbivores on Posidonia oceanica epiphytes. Aquat. Bot., 56: 93-104.

Álvarez, E., M. Cerdà, A. Frau, A. Grau, C. Pons-Fàbregas and D. Carreras. - 2009. Seguimiento de la red de vigilancia de las praderas de Posidonia oceanica en Baleares (2002-2007). In: Instituto de Ecología Litoral, Posidonia oceanica. Redes de seguimiento y estado de conservación en el Mediterráneo es- pañol, pp. 70-90. Diputación de Alicante, Alicante.

Balata, D., U. Nesti, L. Piazzi and F. Cinelli. - 2007. Patterns of spatial variability of seagrass epiphytes in the north-west Mediterranean Sea. Mar. Biol., 151: 2025-2035.

Balestri, E. - 2004. Flowering of the seagrass Posidonia oceanica in a north-western Mediterranean coastal area: temporal and spatial variations. Mar. Biol., 145: 61-68.

Balestri, E., F. Cinelli and C. Lardicci. - 2003. Spatial variation in Posidonia oceanica structural, morphological and dynamic features in a northwestern Mediterranean coastal area: a multiscale analysis. Mar. Ecol. Prog. Ser., 250: 51-60.

Ballesteros, E. - 1987. Estructura i dinamica del poblament algal de les fulles de Posidonia oceanica (L.) Delile als herbeis de Tossa de Mar (Girona). Bullt. Inst. Cat. Hist. Nat., 54: 13-30.

Borowitzka, M.A., P.S. Lavery and M. Van Keulen. - 2006. Epiphytes of Seagrasses. In: A.W.D. Larkum, R.J. Orth and C.M. Duarte (eds.), Seagrasses: Biology, Ecology and Conservation, pp. 463-501. Springer, Dordrecht.

Buia, M.C., M.C. Gambi and M. Dappiano. - 2003. I sistemi a fanerogame marine. Biol. Mar. Medit., 10: 145-198.

Calmet, D., C.F. Boudouresque and A. Meinesz. - 1988. Memorization of nuclear atmospheric tests by rhizomes and scales of the Mediterranean seagrass Posidonia oceanica (Linnaeus) Delile. Aquat. Bot., 30: 279-294.

Dalla Via, J., C.Sturmbauer, G. Schonweger, E. Sotz, S. Mathekowitsch, M. Martin Stifter and R. Rieger. - 1998. Light gradients and meadow structure in Posidonia oceanica: ecomorphological and functional correlates. Mar. Ecol. Prog. Ser., 163: 267-278.

Duarte, C.M. - 1989. Temporal biomass variability and production / biomass relationships of seagrass communities. Mar. Ecol. Prog. Ser., 51: 269-276.

Duarte, C.M. - 1990. Seagrass nutrient content. Mar. Ecol. Prog. Ser., 67: 201-207.

Duarte, C.M., N. Marbà, N.S.R. Agawin, J. Cebrián, S. Enríquez, M.D. Fortes, M.E. Gallegos, M. Merino, B. Olesen, K. SandJensen, J.S. Uri and J.E. Vermaat. - 1994. Reconstruction of seagrass dynamics: age determinations and associated tools for the seagrass ecologist. Mar. Ecol. Prog. Ser., 107: 195-209.

Duarte, C.M., J.W. Fourqurean, D. Krause-Jensen and B. Olesen. 2006. Dynamics of Seagrass Stability and Change. In: A.W.D. Larkum, R.J. Orth and C.M. Duarte (eds.), Seagrasses: Biology, Ecology and Conservation, pp. 271-294. Springer, Dordrecht.

Figueiredo, M.A.O., J.M. Kain and T.A. Norton. - 2000. Responses of crustose corallines to epiphyte and canopy cover. J. Phycol., 36: $17-24$

Fourqurean, J.W., J.C. Zieman and G.V.N. Powell. - 1992. Phosphorus limitation on primary production in Florida Bay: Evidence from C:N:P ratios of the dominant seagrass Thalassia testudinum. Limnol. Oceanogr., 37: 162-171.

Fourqurean, J.W., N. Marbà, C.M. Duarte, E. Díaz Almela and S. Ruiz-Halpern. - 2007. Spatial and temporal variation in the elemental and stable isotopic content of the seagrasses Posidonia oceanica and Cymodocea nodosa from the Illes Balears, Spain. Mar. Biol., 151: 219-232.

Gobert, S. - 2002. Variations spatiale et temporelle de l'herbier à Posidonia oceanica (L.) Delile. $\mathrm{PhD}$ thesis, Universitè de Liège.

Gobert, S., M. Kyramarios, G. Lepoint, C. Pergent-Martini and J.M. Bouquegneau. - 2003. Variations à différentes échelles spatiales de l'herbier à Posidonia oceanica (L.) Delile; effects sur les paramètres physico-chimiques du sédiment. Oceanol. Acta, 26: 199-207.

González-Correa, J.M., J.T. Bayle-Sempere, P. Sánchez-Jerez and C. Valle. - 2007. Posidonia oceanica meadows are not declining globally. Analysis of population dynamics in marine protected areas of the Mediterranean Sea. Mar. Ecol. Prog. Ser., 336: 111-119.

Guidetti, P. - 2001. Detecting environmental impacts on the Mediterranean seagrass Posidonia oceanica (L.) delile: the use of reconstructive methods in combination with 'beyond BACI' designs. J. Exp. Mar. Biol. Ecol., 260: 27-39.

Hillman, K., D.I. Walker, A.W.D. Larkum and A.J. McComb. 1989. Productivity and nutrient limitation. In: A.W.D. Larkum, A.J. McComb and S.A. Shepherd (eds.), Biology of Seagrasses, pp. 635-685. Elsevier, Amsterdam.

Leoni, V., V. Pasqualini, C. Pergent-Martini, A. Vela and G. Pergent. - 2006. Morphological responses of Posidonia oceanica to experimental nutrient enrichment of the canopy water. J. Exp. 
Mar. Biol. Ecol., 339: 1-14.

Leoni, V., V. Pasqualini, C. Pergent-Martini, A. Vela and G. Pergent. - 2007. Physiological responses of Posidonia oceanica to experimental nutrient enrichment of the canopy water. $J$. Exp. Mar. Biol. Ecol., 349: 73-83.

Lepoint, G., S. Havelange, S. Gobert and J.M. Bouquegneau. 1999. Fauna vs flora contribution to the leaf epiphytes biomass in a Posidonia oceanica seagrass bed (Revellata Bay, Corsica). Hydrobiologia, 394: 63-67.

Marbà, N. and C.M. Duarte. - 1997. Interannual changes in seagrass (Posidonia oceanica) growth and environmental change in the Spanish Mediterranean littoral zone. Limnol. Oceanogr., 42: 800-810.

Marbà, N., C.M. Duarte, E. Díaz Almela, J. Terrados, E. Álvarez, R. Martínez, R. Santiago, E. Gacia and A. Grau. - 2005. Direct evidence of imbalanced seagrass (Posidonia oceanica) shoot population dynamics in the Spanish Mediterranean. Estuaries, 28: 53-62.

Marbà, N., R. Santiago, E. Díaz Almela, E. Álvarez and C.M. Duarte. - 2006. Seagrass (Posidonia oceanica) vertical growth as an early indicator of fish farm-derived stress. Estuar. Coast. Shelf Sci., 67: 475-483.

Marbà, N. and C.M. Duarte. - 2010. Mediterranean warming triggers seagrass (Posidonia oceanica) shoot mortality. Global Change Biol., doi:10.1111/j.1365-2486.2009.02130.x

Marullo, S., B. Buongiorno-Nardelli, M. Guarracino and R. Santoleri. - 2007. Observing The Mediterranean Sea from Space: 21 years of Pathfinder-AVHRR Sea Surface Temperatures (1985 to 2005). Re-analysis and validation. Ocean Sci., 3, 299-310.

Mazzella, L., M.B. Scipione and M.C. Buia. - 1989. Spatio-temporal distribution of algal and animal communities in a Posidonia oceanica meadow. P. S. Z. N. I. : Mar. Ecol., 10: 107-129.

McClelland, J.W. and I. Valiela. - 1998. Linking nitrogen in estuarine producers to land-derived sources. Limnol. Oceanogr., 43: 577-585.

Nesti, U., L. Piazzi and D. Balata. - 2009. Variability in the structure of epiphytic assemblages of the Mediterranean seagrass Posidonia oceanica in relation to depth. Mar. Ecol., 30: 276-287.

Orth, R.J., T.J.B. Carruthers, W.C. Dennison, C.M. Duarte, J.W. Fourqurean, K.L. Heck Jr, A.R. Hughes, G.A. Kendrick, W.J. Kenworthy, S. Olyarnik, F.T. Short, M. Waycott and S.L. Williams. - 2009. A global crisis for seagrass ecosystems. BioScience, 56: 987-996.

Pardi, G., L. Piazzi, D. Balata, I. Papi, F. Cinelli and L. BenedettiCecchi. - 2006. Spatial variability of Posidonia oceanica (L.) Delile epiphytes aroun the mainland and the islands of Sicily (Mediterranean Sea). Mar. Ecol., 27: 397-403.

Peirano, A., C.N. Bianchi, D. Savini and G. Farina. - 2001. A longterm monitoring activity on a Posidonia oceanica meadow at Monterosso al mare (Ligurian Sea). Archo Oceanogr. Limnol., 22: $145-148$

Pérez, M., T. García, O. Invers and J.M. Ruiz-Fernández. - 2008. Physiological responses of the seagrass Posidonia oceanica as indicators of fish farm impact. Mar. Pollut. Bull., 56: 869-879.

Pergent, G. and C. Pergent-Martini. - 1990. Some Applications of lepidochronological analysis in the seagrass Posidonia oceanica. Bot. Mar., 33: 299-310.

Pergent-Martini, C., V. Leoni, V. Pasqualini, G.D. Ardizzone, E. Balestri, R. Bedini, A. Belluscio, T. Belsher, J. Borg, C.F. Boudouresque, S. Boumaza, J.M. Bouquegneau, M.C. Buia, S. Calvo, J. Cebrián, E. Charbonnel, F. Cinelli, A. Cossu, G. Di Maida, B. Dural, P. Francour, S. Gobert, G. Lepoint, A. Meinesz, H. Molenaar, H.M. Mansour, P. Panayotidis, A. Peirano, G. Pergent, L. Piazzi, M. Pirrotta, G. Relini, J. Romero, J.L. Sánchez-Lizaso, R. Semroud, P. Shembri, A. Shili, A. Tomasello and B. Velimirov.- 2005. Descriptors of Posidonia oceanica meadows: Use and application. Ecol. Indicators, 5: 213-230.

Piazzi, L. A.M. De Biasi, D. Balata, G. Pardi, S. Boddi, S. Acunto, M. Pertusati, I. Papi, F. Cinelli and G. Sartoni. - 2007. Species composition and spatial variability patterns of morphological forms in macroalgal epiphytic assemblages of the seagrass Posidonia oceanica. Vie Milieu, 57(3): 1-9.

Prado, P., T. Alcoverro and J. Romero. - 2008. Seasonal response of Posidonia oceanica epiphyte assemblages to nutrient increase. Mar. Ecol. Prog. Ser., 359: 89-98.

Procaccini, G., M.C. Buia, M.C. Gambi, M. Pérez, G. Pergent, C. Pergent-Martini and J. Romero. - 2003. The seagrasses of the Western Mediterranean. In: E.P. Green and F.T. Short (eds.), World Atlas of Seagrasses, pp. 48-58. UNEP World Conservation Monitoring Centre, University of California Press, Berkeley.

Romeo, M., M. Gnassia-Barelli, T. Juhel and A. Meinesz. - 1995. Memorization of heavy metals by scales of the seagrass Posidonia oceanica collected in the NW Mediterranean. Mar. Ecol. Prog. Ser., 120: 211-218.

Romero, J. - 1988. Epífitos de las hojas de Posidonia oceanica: variaciones estacionales y batimétricas de biomasa en la pradera de las islas Medes (Girona). Oecol. Aquat., 9: 19-25.

Ruiz, J.M. and J. Romero. - 2001. Effects of in situ experimental shading on the Mediterranean seagrass Posidonia oceanica. Mar. Ecol. Prog. Ser., 215: 107-120.

Ruiz, J.M., M. Pérez and J. Romero. - 2001. Effects of fish farm loadings on seagrass (Posidonia oceanica) distribution, growth and photosynthesis. Mar. Pollut. Bull., 42: 749-760.

Ruiz-Fernández, J.M., R. García-Muñiz, M. García-Martínez, L. Marín-Guirao, J.M. Sandoval-Gil, J. Serón-Aguirre, A. RamosSegura and J. Gavilán-Alonso. - 2009. Red de seguimiento de Posidonia oceanica en la región de Murcia. In: Instituto de Ecología Litoral, Posidonia oceanica. Redes de seguimiento y estado de conservación en el Mediterráneo español, pp. 92112. Diputación de Alicante, Alicante.

Santoleri, R., G. Volpe, S. Marullo and B. Buongiorno-Nardelli. - 2008. Open waters optical remote sensing of the Mediterranean Sea. In: V. Barale and M. Gade (eds.), Remote Sensing of the European Seas, pp. 103-116. Springer Science+Business Media B.V.

Sánchez-Rosas, J. and I. Olivella-Prats. - 2009. La red de vigilancia de la calidad biológica de las fanerógamas marinas en el litoral catalán. In: Instituto de Ecología Litoral, Posidonia oceanica. Redes de seguimiento y estado de conservación en el Mediterráneo español, pp. 26-48. Diputación de Alicante, Alicante.

StatSoft, Inc. - 2005. STATISTICA (data analysis software system), version 7.1. www.statsoft.com.

Terrados, J. and F.J. Medina-Pons. - 2008. Epiphyte load on the seagrass Posidonia oceanica (L.) Delile does not indicate anthropogenic nutrient loading in Cabrera Archipelago National Park (Balearic Islands, Western Mediterranean). Sci. Mar., 72: 503-510.

Tomas, F., X. Turón and J. Romero. - 2005. Effects of herbivores on a Posidonia oceanica seagrass meadow: importance of epiphytes. Mar. Ecol. Prog. Ser., 287: 115-125.

Tsirika, A., G. Skoufas and S. Haritonidis. - 2007. Seasonal and bathymetric variations of epiphytic macroflora on Posidonia oceanica (L.) Delile leaves in the National Marine Park of Zakynthos (Greece). Mar. Ecol., 28: 146-153.

Zupo, V., M.C. Buia and L. Mazzella. - 1997. A production model for Posidonia oceanica based on temperature. Estuar. Coast. Shelf Sci., 44: 483-492.

Scient. ed.: E. Ballesteros.

Received October 27, 2009. Accepted May 12, 2010.

Published online November 23, 2010. 